\title{
Peer Feedback in Reviewing Essay
}

\author{
Utami Dewi $^{1}$
}

${ }^{1}$ Universitas Islam Negeri Sumatera Utara

\begin{tabular}{l}
\hline \hline ARTICLE INFO \\
\hline \hline Article history: \\
Received March 28, 2019 \\
Revised May 02, 2019 \\
Accepted June 15, 2019 \\
\hline Keywords: \\
Peer Feedback, \\
Reviewing, \\
Essay \\
\hline Clonflict of Interest: \\
None
\end{tabular}

Funding:

None

ABSTRACT

Peer feedback is the comment or advice from equal partner, which can help the writer to improve their product of the writing. The aim of this study was to find out the types of peer feedback most frequently given by students in reviewing their classmates' essay. The total participants of this study were 178 students of English education department. The data of this study was taken from peer feedback given by students in reviewing essay, which applied in the class of writing. The design of this study was descriptive quantitative. The peer feedback given by students in reviewing their classmates' essay was analyzed and categorized based on Hyland and Hyland's classification: praise, criticism, and suggestion. As the result, suggestion was most frequently given by students in reviewing essay because most of the students gave constructive comment or asking the improvement as their feedback rather than gave praise and criticism. It was seen that the total suggestion which given by students to the classmates was 208 feedback. Then, 108 praise was given which expressed the positive comments or positive impression, though there is some empty praise without constructive comments. 107 criticisms were also given by students in expressing their negative comment or dissatisfaction with the essay written by their classmates. In addition, some combinations of the feedback were also given in reviewing essay. There are 30 combinations of praise and criticism, 51 combinations of praise and suggestion, and 25 combinations of criticism and suggestion. In conclusion, the reviewers expressed positive and negative comments, positive and constructive comments, the negative and constructive comments in same time.

Corresponding Author: Utami Dewi, English Education Department, Universitas Islam Negeri Sumatera Utara, Jl. Willem Iskandar Ps. V. Medan Estate, Kec. Percut Sei Tuan, Kabupaten Deli Serdang, Sumatera Utara 20371, Indonesia. Email: utamidewi@uinsu.ac.id 


\section{Introduction}

Now days, the focus of teaching writing is not only on the students' product, but also on the process. Writing became important skills to be increased in the classroom. There are many strategies that can be used to improve writing ability. One of the strategies was peer feedback. The students did some of the strategies in reviewing the essay; such as: peer feedback. The students shared their writing to their classmate as the partner, and they got some of feedback. Feedback has long been an important part of teaching second/foreign language writing. It has great potential for learning and student motivation (Hyland and Hyland, 2006), and it helps students understand the advantages and disadvantages of their writing, identify writing problems, and improve their writing competencies consequently (Cai, 2011). With a learning paradigm shift from individual learning to distributed, collaborative learning, peer feedback has witnessed its increased deployment in educational settings and become apopular area for research. In the second language writing context, peer feedback mainly involves students in the activity of forming pairs or groups, reading each other's compositions, and making suggestions for revisions (Mangelsdorf, 1992). Many studies have reported the benefits of utilizing peer feedback, for example, giving more autonomy to students (Mendoca and Johnson, 1994; Mo, 2005), providing a more authentic audience (Mittan, 1989; Caulk, 1994), and offering opportunities for students to evaluate their own work more critically (Cheng and Warren, 1996; Topping et. Al., 2000).

Peer feedback/ peer review is now commonly practiced in the writing classroom as it has been shown to have positive effects on students' writing process and product (Paulus, 1999; Lundstrom \& Baker, 2009). In this research, the peer feedback is applied in writing essay. Besides beneficial effects on the quality of the writing, peer feedback has advantages such as developing critical thinking, learner autonomy and social interaction among students. In this respect, a technique that has received great attention over the last two decades is peer reviewing (Mangelsdorf, 1992; Mittan, 1989; Tsui \& Ng, 2000; McMurry, 2004; etc). Much research has indicated the positive effect of peer reviewing on the writing process and on the writer's product.

Peer feedback can be effective for a variety of reasons when used correctly, especially when students are trained on how to give and use feedback. Teachers can incorporate it as a way to present writing skills to students, ideally creating a student-centered classroom with learners capable of critically evaluating their own written work. Peer review for L2 learners also provides students with the opportunity to use language in the classroom in a meaningful way (Krashen, 1982), thus improving not only their writing but also allowing them to practice their listening and speaking abilities. Peer review sessions can teach students important writing skills, such as writing to a real audience, seeing ideas and points of view other than their own, and discussing how to revise writing effectively. Based on the explanation, the feedback had some positive effects to the students in writing an essay, therefore, peer feedback on writing essay by English education department students is discussed in this article based on the writer's research.

\section{Peer Feedback}

Peer reviewing is referred to as peer feedback, which is an assessment form performed by equal status learners (Gielen et al. 2010). In 'peer review' a student does more than simply editing and evaluating another student's essay. Students respond to what the essay says as well as how it says it (Mangelsdorf, 1992). Peer feedback is when writers read each other's work and make comments or ask questions to help each other improve their writing. The 
best peer feedback is constructive, questioning, supportive, and respectful of the writer's work.

Peer reviewing is a powerful learning tool (e.g. Mangelsdorf, 1992; Diab, 2011; etc.) which provides students with an authentic audience; increases their motivation to write; enables them to receive different views on their writing and read their own writing critically; and assists them in gaining confidence in their writing (Mittan, 1989). Peer review (i.e., peer editing, peer evaluation, or peer feedback), frequently used in both first (L1) and second language (L2) writing classrooms, is an important activity which allows writing teachers to help their students receive more feedback on their papers as well as give students practice with a range of skills important in the development of language and writing ability, such as meaningful interaction with peers, a greater exposure to ideas, and new perspectives on the writing process (Hansen \& Liu, 2005; Mangelsdorf, 1992). The skill of being able to critically evaluate writing, defined as the ability to look at a classmate's writing and then provide effective feedback, particularly on a global level (i.e., at the level of content and organization), is a very necessary skill for quality writing and academic success in general (Gieve, 1998; Thompson, 2002).

Research on the other hand has indicated that peer feedback can also contribute to students' writing (Jacobs, 1987; Tsui \& Ng, 2000; Yang, Badger \& Yu, 2006). Peer review is now commonly practiced in the writing classroom as it has been shown to have positive effects on students' writing process and product (Paulus, 1999; Lundstrom \& Baker, 2009). While research has indicated that teacher feedback tends to generate more comments at the grammatical level, peer feedback can generate more comments on the content, organization, and vocabulary (Paulus, 1999).

In giving peer reviewing, there are many types of feedback that can be used by the students because writing is a personal process where motivation and self-confidence of the students as writers may expand or contract depending on the type of comments incorporated in the feedback. According to Hyland and Hyland (2001), there are three broad types of written feedback: praise, criticism, and suggestion. Praising encourages the reoccurrence of appropriate language behaviors where writers are accredited for some characteristics, attributes or skills (Holmes, 1988). However, praise needs to be credible and informative as false praising is likely to discourage good writing (Cardelle \& Corno, 1981, cited in Hyland \& Hyland, 2001). Furthermore, premature praise may confuse writers and discourage their self-revision. It, therefore, suggests a more intense or detailed response than simple agreement. On the other hand, criticism is a negative comment used by reviewers in expressing their dissatisfaction with the text. Criticism, we define as "an expression of dissatisfaction or negative comment" on a text (Hyland, 2000a, p. 44). Example of teacher comment offering criticism: Poor spelling, not good. Suggestion is the third category of feedback which is related to criticism but has a positive orientation. Suggestion differs from criticism in containing commentary for improvement. Productive suggestion is also known as constructive criticism which includes clear and achievable actions for writers. Suggestion, which we regard as coming from the more positive end of a continuum. Suggestions differ from criticisms in containing an explicit recommendation for remediation, a relatively clear and accomplishable action for improvement, which is sometimes referred to as "constructive criticism." Comments were classified as suggestions if they had included words such as: need to, could, should, would, try, it is better to, it might be better and have to. Example of comment offering suggestion: You need a more general statement to introduce the topic. 


\section{Peer Feedback In Reviewing Essay}

This article focused on the students' peer feedback in reviewing essay that used by the fourth semester of English Education Department students. There were six classes of the fourth semester of English Department students. All of the students in those classes were the participants in this study. The total were 178 students. The peer feedback was applied in the classroom of Writing Skill II. Each student shared the essay with his/her partner. Then, the reviewers gave feedback to their friends' essay writing especially to the introduction, body and conclusion part of their essay writing.

The peer feedback was divided into praise, criticism, suggestion. In addition, sometimes the reviewers gave the peer feedback by using the combination of feedback, such as: combination between praise and criticism, praise and suggestion and the last criticism and suggestion. These categories were analyzed by the researcher to see which category the most frequently used by the students when they wrote their peer feedback. The following tables were the calculation of the types of peer feedback on reviewing essay which used by students of English Education Department.

Table 1: Types of Peer Feedback in Reviewing Essay

\begin{tabular}{llllll}
\hline Type of Feedback & Introduction & Body & Conclusion & Total & Percentages \\
\hline Praise & 39 & 29 & 40 & 108 & 20.4 \\
\hline Criticism & 46 & 33 & 28 & 107 & 20.2 \\
\hline Suggestion & 55 & 67 & 86 & 208 & 39.3 \\
\hline Praise and Criticism & 14 & 12 & 4 & 30 & 5.6 \\
\hline Praise and Suggestion & 14 & 23 & 14 & 51 & 9.6 \\
\hline $\begin{array}{l}\text { Criticism and } \\
\text { Suggestion }\end{array}$ & 10 & 10 & 5 & 25 & 4.7
\end{tabular}

Suggestion

The total calculation of suggestion feedback on reviewing essay which used by English Education Department was 208 students. From the table above, it showed that 39,3\% of students used the suggestion feedback in doing peer revising. Then, the students used praise $(20,4 \%)$, criticism $(20,2 \%)$, combination of praise and suggestion $(9,6 \%)$, combination of praise and criticism (5,9\%), and combination of criticism and suggestion $(4,7 \%)$. From the percentages, it was concluded that the peer feedback which used most frequently on writing essay was suggestion because most of the students gave the constructive comment or asking the improvement as their feedbacks rather than gave the praise and criticism.

Furthermore, the explanation how to classify the types of the peer feedback which used by students was described in the following description which analyzed by content analysis. Although, in the following, it did not describe all of the peer feedback which used, there were only some examples which explained in each category. The examples were taken randomly. In this case, the writer described the reason in identifying the types of feedback.

Praise feedback is one type of peer feedback which expresses the positive comments or positive impression. In addition, the students also like praise and this type of comment is ussually associated with positive feelings.

According to me, the introduction is good, but the background information is too complete. The topic sentence, topic introduction and major subdivision is good. 
From the feed back above, it was categorized to praise because there was a word "good" and "complete". This word is usually used in praise feedback. The next example also uses word "good" but in different expression.

This is good drafting, because background information, topic introduction, topic sentence and major subdivision is clear and easy to understanding.

It is clear, appropriate with the text yesterday.

Same as the feedback above, this feedback also expressed the positive condition because it used the word "clear" and " appropriate".

Some of criticism feedback which used by English Educational Department students were:

In your introduction paragraph, you don't describe subdivision clearly.

You the point of how or what to do in the body movement. So, don't describe

I don't know what will you explain or describe in your body paragraph. All

the word that circled and underlined are ungrammatical.

There were many phrase which used to express negative comments. The phrase "don't describe" was used twice in this feedback. Then there were found "don't know" and " ungrammatical which was identified as the criticism feedback.

From, the body paragraph, I found any some sentence not punctuation well.

This feedback was categorized as the criticism feedback because it used the word "not" which expressed negative comment.

The Suggestion feedback of introduction that used by English Educational Department students were:

\section{You must check again you punctuations again.}

This peer feedback was categorized as suggestion feedback because it used the phase "must check" as suggestion to improve the essay writing.

Subdivision must explain or include your gathering.

The word "must" was used again in this peer feedback so it could be categorized as suggestion feedback.

Feedback above were classified by some the reasons. The reason were also described above as examples. From the description, there were some of the words or expression which used in each category. The words which used to give praise were "good", "complete", "clearly", "suitable", "appropriate", etc. Then, some words which used to give criticism were "not good", "not clear", "wrong", "confused", "mistakes", etc. Lastly, the words or expression which used in suggestion feedback were "please", "put", "attention", "revise", "check", etc. In addition, reviewer used the combination of two feedback in revising their fellow students' essay. There were the combination of praise and criticism, the combination of praise and suggestion, and the combination of criticism and suggestion. It meant that in one feedback, the reviewer used two types of feedback. For example: in one feedback, there were words "complete" and "not clear". So the feedback was classified as the combination of praise and criticism.

\section{Conclusion}

In summary, suggestion feedback was most frequently used by students of English Education Department because most of the students gave the constructive comment or asking the improvement as their feedbacks so that they could improve their essay. It was seen from the total calculation of suggestion feedback on writing essay which used by students of English Education Department was 208 suggestion feedback. It showed that there was 39,3\% suggestion feedback which used by students in doing peer revising. Here 
were some of the instruction words or expressions which used in expressing the suggestion feedback, such as: "please", "revise", "check", "attention", "write", "put", "use", etc. Those instruction words were found to give the constructive comments or ask the improvement. Then, some of positive expression such as: "good", "complete", "clear", etc. were used in praise. On the other hand, there were some negative expression which used by students, such as: "not good", "not suitable", "wrong", "ungrammatical", "not clear", etc.

\section{References}

Cai L, et al. (2011) Acetyl-CoA induces cell growth and proliferation by promoting the acetylation of histones at growth genes. Mol Cell 42(4):426-37

Caulk, N. 1994. Comparing teacher and students responses to written work. TESOL Quarterly, 28 (1). 181-188. Doi:102307/3587209

Cardelle, M., \& Corno, L. (1981). Effects on second language learning of variations in written feedback on homework assignments. TESOL Quarterly, 15 (3), 251-261.

CHENG, W, \& WARREN, M. (1996) I-long Kong students' attitudes towards peer assessment on English language courses, Asian Journal 0/ English Language Teaching, 6, pp 61-75

Gieve, S. (1998). Comments on Dwight Atkinson's "A critical approach to critical thinking in TESOL.'” TESOL Quarterly, 32, 123-129.

Gielen, S., Peeters, E., Dochy, F., Onghena, P., \& Struyven, K. (2010). Improving the effectiveness of peer feedback for learning. Learning and Instruction, 20(4), 304315.

Hansen, J., \& Liu, J. (2005). Guiding principles for effective peer response. ELT Journal, $59,31-38$.

Holmes, J. (1988). Doubt and certainty in ESL textbooks. Applied Linguistics, 91, 20- 44.

Hyland, F. (2000). ESL writers and feedback: Giving more autonomy to students. Language Testing Research, 4, 33-54.

Hyland, K. (2000a). Disciplinary discourses: Social interactions in academic writing. London: Longman.

Hyland, F., \& Hyland, K. (2001). Sugaring the pill: Praise and criticism inwritten feedback. Journal of Second Language Writing, 10, 185-212.

Hyland, K. \&. Hyland F. (2006). Feedback in Second Language Writing: Contexts and Sources. New York: Cambridge University Press.

Jacobs, G. (1987). First experiences with peer feedback on compositions: Student and teacher reaction. System, 15(3), 325-333.

Krashen, Stephen. (1982). Principles and practice in second language learning and acquisition. Oxford: Pergamon.

Lundstrom, K., \& Baker, W. (2009). To give is better than to receive: The benefits of peer review to the reviewer's own writing. Journal of Second Language Writing, 18(1), $30-43$.

Mangelsdorl, K. (1992). Peer reviews in the ESL composition classroom: What do the students think? ELT Journal, 46, 274-284.

McMurry, A. I. (2004). Preparing students for peer review. Unpublished master's project. Provo, UT: Brigham Young University. 
Mendonça, C. \& Johnson, K. E. "Peer review negotiations: Revision activities in ESL writing instruction.” TESOL Quarterly 28 (4): 745-69, 1994.

Mittan, R. "The peer review process: harnessing students' communicative power." In D. Johnson and D. Roen (eds.), Richness in writing: empowering ESL students : 20719, New York: Longman, 1989.

Paulus, T. M. (1999). The effect of peer and teacher feedback on student writing. Journal of Second Language Writing, 8(3), 265-289.

Thompson, C. (2002). Teaching critical thinking in EAP courses in Australia. TESOL Journal, 11, 15-20.

Topping, KJ (1998). Peer assessment between students in colleges and universities. Review of Educational Research, 68, 249-276.

Tsui, A. B. M., \& Ng, M. (2000). Do secondary L2 writers benefi t from peer comments? Journal of Second Language Writing, 9(2), 147-170.

Yang, M., Badger, R., \& Yu, Z. (2006). A comparative study of peer and teacher feedback in a Chinese EFL writing class. Journal of Second Language Writing, 15, 179-200. 